\title{
СВОЙСТВА ШТАММОВ ВАCILLUS SUВTILIS КАК ПРОДУЦЕНТОВ АМИЛАЗ ПРИ ПРОИЗВОДСТВЕ САХАРОСОДЕРЖАЩЕЙ КОРМОВОЙ ДОБАВКИ
}

\author{
N. V. Donkova, S. A. Donkov
}

\section{THE PROPERTIES OF BACILLUS SUBTILIS STRAINS AS AMYLASE PRODUCERS IN THE PRODUCTION OF SUGAR-CONTAINING FODDER ADDITIVE}

\begin{abstract}
Донкова Наталья Владимировна - д-р ветеринар. наук, проф., зав. каф. анатомии, патологической анатомии и хирургии Красноярского государственного аграрного университета, г. Красноярск. E-mail:dnv-23@mail.ru
\end{abstract}

Донков Сергей Александрович - канд. биол. наук, доц. каф. анатомии, патологической анатомии и хирургии Красноярского государственного аграрного университета, г. Красноярск.

E-mail:dnv-23@mail.ru

Цель исследования - изучение сравнительной амилолитической активности у штаммов Bacillus subtilis как продуцентов амилаз при производстве сахаросодержащей кормовой добавки. В задачи исследования входило: 1) изучение амилолитической активности у трех штаммов микроорганизма Bacillus subtilis: штамма № 2-amylolytic, uтамма № 9-amylolytic u штамма № 12-amylolytic; 2) установление количества спор каждого штамма, дающих максимальный амилолитический эфффект. Приводятся результаты изучения амилолитической активности у различных штаммов микроорганизма Ваcillus subtilis. Разрабатьваемая технология предусматривает применение одного из uтаммов микроорганизма Bacillus subtilis в качестве продуцента амилолитического фермента с целью получения из крахмала сахаросодержащей кормовой добавки, предназначенной для телят. Установлена амилолитическая активность различных штаммов микроорганизма Bacillus subtilis: № 2-amylolytic, № 9-amylolytic u № 12-amylolytic, - c определением количества спор в штаммах, дающего максимальный амилолитический эфффрект. Показано, что наивысшая амилолитическая активность определяется у штамма Bacillus subtilis № 12-amylolytic, средняя - у штамма Bacillus subtilis № 9-amylolytic и наименьшая - у штамма
Donkova Natalya Vladimirovna - Dr. Veterinary Sci., Prof., Head, Chair of Anatomy, Pathological Anatomy and Surgery, Krasnoyarsk State Agrarian University, Krasnoyarsk.

E-mail: dnv-23@mail.ru

Donkov Sergey Alexandrovich - Cand. Biol. Sci., Assoc. Prof., Chair of Anatomy, Pathological Anatomy and Surgery, Krasnoyarsk State Agrarian University, Krasnoyarsk.

E-mail: dnv-23@mail.ru

Bacillus subtilis № 2-amylolytic. Количество спор, дающее максимальный амилолитический эфрфект у разных штаммов, в среднем составило 125000 спор/мл. Применение телятам сахаросодержащей кормовой добавки позволяет не только обеспечить их организм сахарами, но и повысить переваримость крахмала, который nоступает в желудочно-кишечный тракт телят с растительным кормом. Кроме того, содержащиеся в сахаросодержащей кормовой добавке штаммы микроорганизмы Bacillus subtilis обладают антагонистической активностью по отношению к энтеропатогенным бактериям, m. е. такая добавка обладает пробиотическими свойствами, и потому ее применение будет не только устранять дефицит сахаров в рационе, но и профилактировать желудочнокишечные заболевания у телят.

Ключевые слова: сахаросодержащая кормовая добавка, пробиотик, амилолитическая активность, Bacillus subtilis.

The research objective was studying comparative amylolytic activity in various strains of the microorganism Bacillus subtilis when producing sugarcontaining fodder additive. The research problems included: 1) studying amilolitic activity at three strains of Bacillus subtilis microorganism: strain № 2-amylolytic, strain № 9-amylolytic and strain 
№ 12-amylolytic; 2) the establishment of the quantity of spores of each strain, giving the maximum amilolitic effect. The results of studying amilolitic activity at various strains of Bacillus subtilis microorganism are given. Developed technology provides the application of one of Bacillus subtilis microorganism strains as a producer of amilolitic enzyme for the purpose of receiving from the starch of sugarcontaining fodder additive intended for calves. Amilolitic activity of various strains of Bacillus subtilis microorganism was established: № 2-amylolytic, № 9-amylolytic and № 12-amylolytic, - with the definition of the quantity of spores in the strains giving the maximum amilolitic effect. It was shown that the highest amilolitic activity had been defined at a strain of Bacillus subtilis № 12 - by amylolytic, average at a strain of Bacillus subtilis № 9-amylolytic and the smallest - at the strain of Bacillus subtilis № 2-amylolytic. The quantity of the spores giving the maximum amilolitic effect at different strains, averaged 125000 spores $/ \mathrm{ml}$. Feeding the calves with sugar-containing fodder additive allows not only to provide their organism with sugars, but also to increase the digestibility of the starch which comes to digestive tract of the calves with vegetable forage. Besides, the strains containing in sacchariferous feed additive microorganisms of Bacillus subtilis possess antagonistic activity in relation to enteropatogennic bacteria, i.e. such additive possesses pro-biotic properties and therefore its application will not only eliminate deficiency of sugars in a diet, but also prevent gastrointestinal diseases at calves. In addition, the strains of Bacillus subtilis of sugar-containing feed additive have antagonistic activity towards enteropathogenic bacteria, i.e. such additive has probiotic properties, and therefore its use will not only eliminate sugar deficiency in the diet, but also prevent gastrointestinal diseases in calves.

Keywords: sugar-containing feed supplement, probiotic, amylolytic activity, Bacillus subtilis.

Введение. В нашей стране и за рубежом для производства пробиотических препаратов используются микроорганизмы, являющиеся представителями семейств Lactobacillus и Bifidobacterium. В последнее время в таком качестве стали использовать и спорообразующие бактерии, в основном из рода Bacillus.

Представители рода Bacillus отличаются высоким и разнообразным спектром биологической активности, обладая выраженным антаго- низмом к патогенным микроорганизмам, они способны продуцировать целый ряд ферментов, расщепляющих крахмал, целлюлозу, белки, жиры [1].

Способность спорообразующих бактерий оказывать пробиотическое действие привела к разработке на их основе препаратов, отнесенных к поколению так называемых биоэнтеросептиков - «самоэлиминирующихся антагонистов» (бактерии, которые не являются специфичными обитателями желудочно-кишечного тракта и которые, как правило, быстро выводятся из организма). К настоящему времени на основе спорообразующих бактерий в мире создано около пятидесяти таких препаратов, например, Bio-Vita, Miyarisan, Biosubtil и др. [2].

Российскими учеными на основе представителей рода Bacillus для медицины и ветеринарии разработано более двадцати пробиотических препаратов, к ним относятся «Бактиспорин», «Биоспорин», «Витаспорин», «Ветбактерин» и др. [3]. Эти пробиотики представляют собой различные штаммы живых бактерий Ваcillus subtilis, подвергнутых либо лиофильному высушиванию и представляющие собой порошкообразную лекарственную форму, либо жидкую форму, являющуюся накопительной культуральной средой с микроорганизмами. Все они устойчивы к антибиотикам и обладают антагонистической активностью по отношению к энтеропатогенным бактериям. Пробиотики применяют с целью восстановления микросрлоры желудочно-кишечного тракта при его диссрункциях различной этиологии и после применения антибиотиков. Кроме того, учеными разработаны споросодержащие пробиотики в виде мази для наружного применения для заживления ран («Биосептин»), а также пробиотики, применяемые для санации мест содержания животных («Субтилис») и коррекции микробиоценоза гениталий у коров («Сахабактисубтил»).

В своей работе [4], посвященной расшифровке геномных детерминант гидролиза крахмала у ряда микроорганизмов, авторы показали, что амилазная активность микробов является результатом сложного преобразования генетической программы клетки. При этом решающее значение для подтверждения способности того или иного микроорганизма расщеплять крахмал имеет значение не наличие гена а-амилазы в его геноме, а экспериментальное обнаружение амилазной активности. Данное наблюдение на- 
ходится в русле современной концепции [5] о приоритете функциональной активности белков над их генетической программой и обуславливает важность разработки экспресс-методов оценки экспрессии амилаз в микробных клетках.

Цель исследования: изучение сравнительной амилолитической активности у штаммов Ваcillus subtilis как продуцентов амилаз при производстве сахаросодержащей кормовой добавки.

В задачи исследования входило: 1) изучение амилолитической активности у трех штаммов микроорганизма Bacillus subtilis: штамма № 2-amylolytic, штамма № 9-amylolytic и штамма № 12-amylolytic; 2) установление количества спор каждого штамма, дающего максимальный амилолитический эффеект.

Материал и методы исследования. Экспериментальное исследование проведено в условиях научно-производственной лаборатории Института прикладной биотехнологии и ветеринарной медицины Красноярского ГАУ, а также в научно-исследовательском испытательном центре Красноярского ГАУ. Амилолитическую активность изучали у трех штаммов микроорганизма Bacillus subtilis: у штамма № 2-amylolytic, штамма № 9-amylolytic и штамма № 12amylolytic. Микроорганизмы были выделены из предоставленного нами материала в ФГУП ГосНИИгенетика (Москва) и приняты на национальное патентное депонирование во Всероссийскую коллекцию промышленных микроорганизмов (ВКПМ). Там же было установлено, что данные штаммы продуцируют амилолитический фрермент, расщепляющий крахмал до глюкозы. Данные штаммы используются нами для получения сахаросодержащей кормовой добавки, которая содержит в своем составе до $70 \%$ сахаров и предназначена для телят. Ее скармливание увеличивает привесы и повышает сохранность телят [6]. Лечебно-профилактический эфффект обусловлен наличием в патоке обозначенных пробиотических штаммов Bacillus subtilis, которые обладают антагонистической активностью по отношению к ряду энтеропатогенных микроорганизмов [7].

Тест на продукцию штаммами амилазы проводили согласно методике, представленной в [8] в нашей модификации. Для этого готовили чашки Петри, в которые наливали горячую питательную среду, состоящую из 1,5 \%-го агар-агара и 1 \%-го крахмала. После застывания среды на ее поверхность наливали раствор Люголя. Среда при- обретала темно-синий цвет. Избыток раствора Люголя сливали, а после высыхания на поверхность среды накладывали 3 бумажных диска диаметром по 5 мм, на каждый диск накапывали по одной капле культуральной жидкости определенного штамма. Амилолитическую активность штаммов оценивали по величине диаметра зоны обесцвечивания йода вокруг бумажного диска. Чашки Петри на одни сутки помещали в термостат, в котором поддерживалась температура $39^{\circ} \mathrm{C}$, на следующий день определяли диаметры зон обесцвечивания йода вокруг бумажных дисков. Параллельно ставили контрольную пробу, где вместо культуральной жидкости использовали дистиллированную воду.

Споры штаммов получали в условиях научнопроизводственной лаборатории кафедры. Определение количества спор каждого штамма, содержащихся в культуральных жидкостях, проводили согласно методике, изложенной в [9], с применением счетной камеры Горяева.

Для получения статистически достоверных результатов все исследования проводили с 3-кратной повторяемостью.

Микроскопию и фотографрирование изучаемого материала проводили при помощи микроскопа МИКМЕД-6 с тринокулярной насадкой и цифрового фотоаппарата Canon-A520, имеющего программное обеспечение для компьютерной обработки получаемых изображений.

Для статистического анализа полученных данных использовали математические функции, заложенные в электронных таблицах Microsoft Excel. Различия между штаммами считались достоверными при $p \leq 5$.

Результаты исследования. В контрольных чашках Петри вокруг капель дистиллированной воды не наблюдали зон обесцвечивания йода.

Данные по изучению амилолитической активности трех штаммов Bacillus subtilis представлены на рисунках 1, 2 и в таблице.

На рисунке 1 представлена чашка Петри, характеризующая амилолитическую активность у вcex 3 штаммов Bacillus subtilis - штамма № 2amylolytic, штамма № 9-amylolytic и штамма № 12-amylolytic. На плотную питательную среду, окрашенную йодом в синий цвет, помещены три бумажных диска, на каждый из которых были нанесены по одной капле культуральной жидкости определенного штамма, содержащей споры в количестве 125000 спор/мл. 




Puc. 1. Зоны обесцвечивания йода различными штаммами

Как видно из рисунка 1, зоны обесцвечивания йода у разных штаммов имели различный диаметр, что говорит о различной амилолитической активности фермента, продуцируемого каждым штаммом.
Результаты измерения диаметров зон обесцвечивания крахмала вокруг бумажных дисков в зависимости от количества спор Bacillus subtilis, содержащихся в культуральной жидкости, нанесенной на бумажные диски, представлены в таблице.

\section{Размер диаметра зон обесцвечивания йода у разных штаммов, мм (M士m)}

\begin{tabular}{|l|c|c|c|}
\hline \multirow{2}{*}{$\begin{array}{c}\text { Кол-во внесенных } \\
\text { спор (Мср) }\end{array}$} & \multicolumn{3}{|c|}{ Диаметр зоны обесцвечивания йода } \\
\cline { 2 - 4 } & № 2-amylolytic & № 9-amylolytic & № 12-amylolytic \\
\hline 50000 спор/мл & $8 \pm 0,35$ & $15 \pm 0,53$ & $20 \pm 0,67$ \\
\hline 75000 спор/мЛ & $17 \pm 0,30$ & $24 \pm 0,50$ & $31 \pm 0,60$ \\
\hline 100000 спор/мЛ & $25 \pm 0,28$ & $31 \pm 0,45$ & $40 \pm 0,56$ \\
\hline 125000 спор/мЛ & $29,5 \pm 0,20$ & $37 \pm 0,35$ & $46,3 \pm 0,40$ \\
\hline 150000 спор/мЛ & $29,5 \pm 0,20$ & $37 \pm 0,35$ & $46,3 \pm 0,40$ \\
\hline
\end{tabular}

Из данных, представленных в таблице, видно, что максимальные зоны обесцвечивания йода были у всех изучаемых штаммов Bacillus subtilis при содержании в 1 мл культуральной жидкости 125000 спор. При этом наибольший диаметр зоны обесцвечивания йода был у штамма № 12amylolytic, он составил 46,3 0,40 мм, а наименьший - у штамма № 2-amylolytic $(29,5 \pm 0,20)$. У штамма № 9-amylolytic диаметр зоны обесцвечи- вания йода составил $37 \pm 0,35$ мм, что соответствует средней амилолитической активности.

Диаметр зоны обесцвечивания у всех трех штаммов зависел от количества спор, внесенных на бумажный диск. Зависимость диаметра зон обесцвечивания йода от количества спор, содержащихся в 1 мл культуральной жидкости, представлена на графике рисунка 2. 


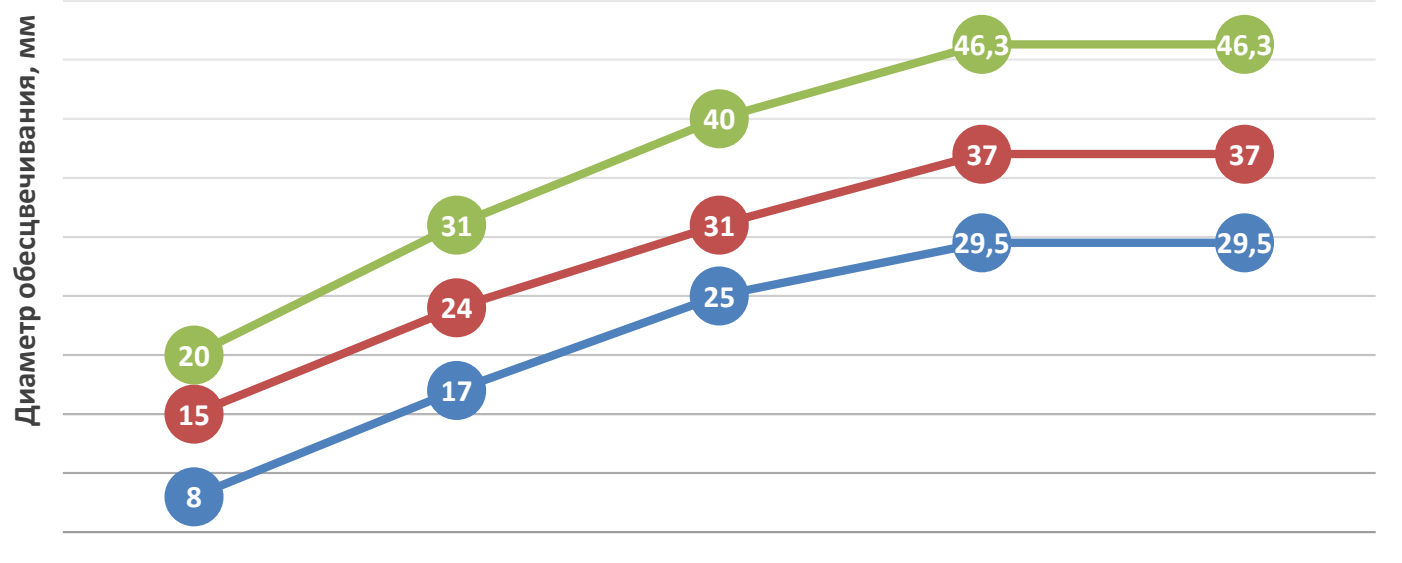

50000 СПОР/МЛ 75000 СПОР/МЛ 100000 СПОР/МЛ 125000 СПОР/МЛ 150000 СпОР/МЛ

—Диаметр зон обесцвечивания йода, мм; —- Диаметр зон обесцвечивания йода, мм;

- Диаметр зон обесцвечивания йода, мм;

Puc. 2. Зависимость диаметра зон обесцвечивания йода от количества спор в 1 мл культуральной жидкости

Из графика, представленного на рисунке 2, следует, что с увеличением количества спор увеличивалась зона обесцвечивания йода.

Количество спор, дающее максимальные диаметры зон обесцвечивания йода, а значит и максимальный амилолитический эфффект, у всех трех штаммов Bacillus subtilis было установлено в количестве 125000 спор/мл, при этом с увеличением количества спор в культуральной жидкости с 50000 спор/мл на каждые 25000 спор/мл приводило к пропорциональному увеличению диаметра зон обесцвечивания йода у всех трех штаммов Bacillus subtilis: № 2-amylolytic, № 9amylolytic, № 12-amylolytic. Увеличение количества вносимых спор свыше 125000 спор на 1 мл не приводило к росту зоны обесцвечивания йода у всех исследуемых штаммов Bacillus subtilis.

Выводы. Сравнительный анализ трех исследуемых штаммов Bacillus subtilis показал, что они обладают различной амилолитической активностью. Наивысшей амилолитической активностью обладает штамм Bacillus subtilis № 12amylolytic, средней - штамм Bacillus subtilis № 9amylolytic и наименьшей - штамм Bacillus subtilis № 2-amylolytic.

Степень амилолитической активности зависит от количества спор в культуральной жидкости. Увеличение количества спор на каждые
25000 спор/мл приводит к пропорциональному увеличению диаметра зон обесцвечивания йода у всех трех штаммов Bacillus subtilis: № 2amylolytic, № 9-amylolytic, № 12-amylolytic. Количество спор, дающее максимальный амилолитический эфффект, у всех трех исследуемых штаммов, составляет 125000 спор/мл.

В качестве продуцента амилолитического фермента в технологии получения из крахмала сахаросодержащей кормовой добавки, предназначенной для телят, рекомендуется применение штамма Bacillus subtilis № 12-amylolytic c содержанием в культуральной жидкости не менее 125000 спор/мл.

\section{Литература}

1. Похиленко В.Д., Перельгин В.В. Пробиотики на основе спорообразующих бактерий и их безопасность // Химическая и биологическая безопасность. 2007. № 2. С. 32-33.

2. Нутрициологические, микробиологические, генетические и биохимические основы разработки и производства продуктов с пробиотиками: монография / И.С. Полянская [и др.]. Вологда-Молочное: Изд-во ВГМХА, 2013. $200 \mathrm{c}$. 
3. Овсянников Ю.С., Тихонов Г.И., Голунова О.В. Пробиотики в ветеринарии // Ветеринарная медицина. 2009. № 1-2. С. 66-68.

4. Сравнительная характеристика амилолитической активности грамположительных бактерий / Н.Л. Бруслик [и др.] // Вестник ВГУ. Сер. Химия. Биология. Фармация, 2014. № 2. C. 47-51.

5. Свердлов Е.Д. Микрокосм гена // Молекулярная биология. 1999. Т. 33. С. 917-940.

6. Донкова Н.В., Донков С.А. Биотехнология получения легкоусвояемых сахаров из зерна для животноводства // Вестник КрасГАУ. 2018. № 1. C. 222-227.

7. Донкова Н.В., Донков С.А. Изучение антагонистической активности амилолитических штаммов Bacillus subtilis // Международный вестник ветеринарии. 2016. № 2. С. 46-50.

8. ОФС 42. Требования к штаммам микроорганизмов, используемые для производства пробиотиков для медицинского применения. URL: https://base.garant.ru/70457452/ 6aab82beaae3d4fd84e6a2f407788ed8 (дата обращения: 05.03.2020).

9. ОФС.1.7.2.0008.15. Определение концентрации микробных клеток. URL: http://ivo.garant.ru/\#/basesearch (дата обращения: 15.03.2020).

\section{Literatura}

1. Pohilenko V.D., Perelygin V.V. Probiotiki na osnove sporoobrazujushhih bakterij i in bezopasnost' // Himicheskaja i biologicheskaja bezopasnost'. 2007. № 2. S. 32-33.

2. Nutriciologicheskie, mikrobiologicheskie, geneticheskie i biohimicheskie osnovy razrabotki i proizvodstva produktov s probiotikami: monografija / I.S. Poljanskaja [i dr.]. Vologda-Molochnoe: Izd-vo VGMHA, 2013. 200 s.

3. Ovsjannikov Ju.S., Tihonov G.I., Golunova O.V. Probiotiki v veterinarii // Veterinarnaja medicina. 2009. № 1-2. S. 66-68.

4. Sravnitel'naja harakteristika amiloliticheskoj aktivnosti grampolozhitel'nyh bakterij / N.L. Bruslik [i dr.] // Vestnik VGU. Ser. Himija. Biologija. Farmacija, 2014. № 2. S. 47-51.

5. Sverdlov E.D. Mikrokosm gena // Molekuljarnaja biologija. 1999. T. 33. S. 917-940.

6. Donkova N.V., Donkov S.A. Biotehnologija poluchenija legkousvojaemyh saharov iz zerna dlja zhivotnovodstva // Vestnik KrasGAU. 2018. № 1. S. 222-227.

7. Donkova N.V., Donkov S.A. Izuchenie antagonisticheskoj aktivnosti amiloliticheskih shtammov Bacillus subtilis // Mezhdunarodnyj vestnik veterinarii. 2016. № 2. S. 46-50.

8. OFS 42. Trebovanija $\mathrm{k}$ shtammam mikroorganizmov, ispol'zuemye dlja proizvodstva probiotikov dlja medicinskogo primenenija. URL: https://base.garant.ru/70457452/6aab82beaa e3d4fd84e6a2f407788ed8 (data obrashhenija: 05.03.2020).

9. OFS.1.7.2.0008.15. Opredelenie koncentracii mikrobnyh kletok. URL: http://ivo.garant.ru/\#/ basesearch (data obrashhenija: 15.03.2020). 